book has a useful bibliography and a well-organised index, but it lacks a glossary of key terms, which many laymen, and even most non-Muslim undergraduate and postgraduate students of Islam, would find to be an invaluable resource.

Collectively, the chapters in this book give us insights into the complexity of the issues surrounding the notion and manifestations of innovation in Islam. In this book, it becomes evident that 'innovation' and all that it implies remains deeply contested in Islam in the fields of literature and the arts, hermeneutics and epistēme, gender and race relations and representations, perceptions of 'the other', and Islam's place in the modern world. These chapters provide definitive answers to various questions that have long preoccupied observers and believers alike insofar as change and innovation within Islam are concerned.

In sum, this splendid collection of provocative essays - addressing the issues from several different perspectives and in various contexts - provides a broad introduction to the topic of innovation in Islam. There are many chapters that are actually 'must reads' for everyone interested in modern trends in Islamic thought.

\title{
Notes
}

1. Bernard Lewis, What Went Wrong? The Clash Between Islam and Modernity in the Middle East (Oxford: Oxford University Press, 2002).

2. Nașr Abū Zayd (an Egyptian Muslim thinker and one of the leading liberal theologians, famous for his project of a 'humanistic qur'ānic hermeneutics') has written various works on this theme both in Arabic and English; for example: Rationalism in Exegesis: A Study of the Problem of Metaphor in the Writing of the Mutazilites (Beirut and Casablanca, 1982); The Concept of the Text: A Study of the Qura'nic Sciences (Beirut and Cairo, 1991); The Problematic of Reading and the Method of Interpretation (Beirut and Casablanca, 1995); Rethinking the Qur'an: Towards a Humanistic Hermeneutics (Utrecht, 2004). He has also written various articles and essays on the same theme, among them "Linguistic Exposition of God in the Qur'ān", "The Textuality of the Koran", and "Divine Attributes in the Qur'an: Some Poetic Aspects".

\section{Alwi Shihab, Examining Islam in the West: Addressing Accusations and Correcting Misconceptions}

(Jakarta: PT Gramedia Putaka Utama Publishing, 2011), 258 pp.

ISBN: 978-979-22-6771-6. Rp77,900

\section{Zarina Nalla International Institute of Advanced Islamic Studies (IAIS) Malaysia}

This book is no doubt an eye-opener and reflects the thoughts of an individual who is unique: an academician with a passion for inter-religious understanding who was a former foreign minister of Indonesia and a graduate of two diametric worlds of education: the Middle East and the United States of America. 
Alwi Shihab earned a doctorate in Islamic studies from Ain Shams University in Cairo and a second doctorate, in 1996, from Harvard University's Center for the Study of World Religions. Currently he is the Indonesian president's special envoy to the Middle East and the Organization of the Islamic Conference (OIC). His years of interaction with the different communities in diverse environments - academia, business, and politics - have led him to publish his understanding and analysis of Christian-Muslim relations and prescriptions on how to ease conflict in this book, which was launched in April 2011 in the Indonesian capital Jakarta.

This recent publication is in fact the English version of an earlier Indonesian volume, published in 2004 under the title Membedah Islam di Barat (Dissecting Islam in the West). The English translation was completed by Dr Ralph B. Brown from Brigham Young University in the United States and Mrs Rumtini from Indonesia.

The author emphasises that the differences between the three major religions Christianity, Islam, and Judaism - can be traced back to misunderstandings on each side of the divide of their own religion and of 'the other'. It is thus imperative that Jews, Christians and Muslims celebrate their common spiritual roots and hopes without prejudice. This book is an attempt to do just that. His core motivation to write this book came from the internet discussions he had with his students in the United States - the majority of whom were non-Muslims - during his years lecturing at Temple University, the Hartford Seminary, and the Harvard Divinity School. Shihab opened an online listserv which served as an important platform for his students to challenge him and provide feedback. When he approached the scholars at Temple University with his idea, the project received wholehearted support and he was advised to write his book in English so that it could serve as a source of reference for religious instructors at universities.

The author reiterates the importance of teaching religions without the valuejudgments of the various faiths. In his own words: "I try only to explain the teachings of the religion, its history, and its contribution toward humanity and civilization without making judgments as to whether a particular religion's values and perspectives are better than another's, more correct than another's or more apt to bring salvation than another's." This is an instructional method which departments of religion and religious studies at Western universities adopt and which should also be practised, according to Shihab, by others as he opines that greater harmony can be created.

The author advocated this approach in his home-country Indonesia, and it is currently being applied at Gajah Mada University in Yogyakarta at the Master's programme. It is critical to teach students to not only understand intimately their own religion, but also to appreciate and respect the positive aspects of the religions of others. 
The need for this becomes even more acute when ethnicity and religion become politicised and the media fails to play a unifying role in some countries. Says Shihab: "If in the academic world a friend can be added every day, in the world of politics, an enemy is born every minute [...]. Those who are engaged in the world of politics are in great need of frequent ethical and moral reminders." The university campus then becomes the last bastion of hope, if you like to set the record straight.

There are three forewords to the book, namely from Dr Franz Maginis-Suseno (a Roman Catholic priest), Dr Nurcholish Madjid (d. 2005) from Pramadina University, who was in his homeland affectionately known as 'Cak Nur', a prominent Indonesian Muslim intellectual, and Boyd K. Packer, the current president of the Quorum of the Twelve Apostles of the Church of Jesus Christ of Latter-Day Saints in the United States.

Shihab traces America's religious history and identifies several paradoxes: for instance, while the United States is identified as a secular and materialistic country and is the first nation to constitutionally separate the church and state, "Americans typically consider themselves more religious than all other nations, since for them, this separation of church and state only demonstrates how important the role of religion remains in the development of their national culture, independent of government coercion." History also demonstrates that no other country has recognised as many religions as the United States. Shihab describes that nation as the "world's only microcosm of world religions". According to Shihab, it is also ironical that religious leaders and government agencies in the United States would mutually support and protect each other. While rallying for national goals, religious leaders would simultaneously also point out how the churches and their doctrines are unable to fulfil the needs of their followers. The concept that ' $\mathrm{God}$ is dead' which originated in Europe is alien to Americans, although religious leaders would rally for national goals.

This overt cooperation between church and state is rarely found in Europe, making the religious environment there very different from that in the United States. The author then delves into some historical roots and causes: the French Revolution, the rise of anticlerical and anti-religious feelings together with the flourishing of 'institutional secularism'. This is compared with the United States where its religious history and patterns obstruct the type of secularism and modernism that exist in Europe. Instead there is an inclination to liberalism in religion. He illustrates this with the American attitude towards the hija $\bar{b}$ issue which is juxtaposed to the current French treatment of the same matter.

The author devotes one full chapter to explaining the turbulent relationship that exists between Islam and Christianity, which he feels is important as a background. He falls back on history greatly to make readers understand the sources of the conflict that arose between the two great religions. According to him, the early 
history of Islam demonstrates the closeness between the Muslim and Christian communities. However, all of this supposedly changed when with the territorial expansion of Islam following the death of Muhammad, Islam was then seen by many of the conquered as a 'religion of the sword'. Says Shihab: "It can be said that there has never been an objective and non-prejudiced view of Islam from the Christian world since the death of the Prophet until the beginning of the twentieth century", although one might argue that this judgment seems to be a little bit one-sided. In Shihab's view, the deep hostility towards Islam can be traced to the Christian Middle Ages, although, he argues, the level of intensity is easing today.

His years of teaching led him to conclude that the majority of students have a negative perception of Islam and think that it is a superficial religion. However, the consolation was that a large number of students wanted to understand Islam first-hand and were willing to change their outlook of the religion. Hence they kept an open mind which then gave the instructor a chance to reach out and share. One of the most commonly asked questions was one revolving around mixed marriages between Muslims and non-Muslims. He was also asked how about whether Jesus in Islam is seen as a Muslim, and it took him an hour just to address this one question alone. American students were especially curious about Sufism or Islamic mysticism, and hence the author dedicated a chapter to this issue to address the overwhelming number of questions he received on this subject. In sum, one could well say that Muslim intellectuals have a challenging road ahead but must rise to this occasion.

In closing, Alwi Shihab's Examining Islam in the West is an inspiring book as it deals with serious issues in a light and informative way. 